\title{
Pulmonary immune cells in health and disease: mast cells and basophils
}

\author{
J.A. Warner*, C. Kroegel**
}

Pulmonary immune cells in health and disease: mast cells and basophils. J.A. Warner, C. Kroegel. OERS Journals Ltd 1994.

ABSTRACT: Mast cells and basophils are multifunctional immune cells and have been implicated in the pathogenesis of asthma and other pulmonary diseases. Although they are derived from distinct lineages, they share a number of important features which justifies discussing them collectively.

This review covers the cellular characteristics and biological properties of both cell types, including origin, maturation and differentiation, morphological and phenotypical properties, as well as their capacity to secrete preformed and newly generated mediators of inflammation. In addition, the mechanisms of cell activation and priming of mast cells and basophils will be outlined, as well as the putative mechanisms through which both cell types communicate with other inflammatory cells.

The final section of the review focuses on the possible pathogenetic role of mast cells and basophils in several pulmonary diseases, such as parasitic infections, allergic diseases, pulmonary fibrosis and malignant disorders.

Eur Respir J., 1994, 7, 1326-1341.
*Dept of Physiology and Pharmacology, University of Southampton, Southampton, UK. **Dept of Pneumology, University Medical Clinics, Freiburg i.Br., Germany.

\section{Correspondence: J. Warner}

Dept of Physiology and Pharmacology

University of Southampton

Bassett Crescent East

Southampton, SO9 3TU UK

Keywords: Basophil, immunoglobulin E, mast cell, mediators, role in human disease, surface receptors

Received: May 51994

Accepted for publication May 181994
Mast cells and basophils express high affinity immunoglobulin E (IgE) receptors (FceRI) on their cell surface and their numerous granules contain substantial amounts of histamine [1, 2]. The release of histamine, and other inflammatory mediators, from these cells is a critical early step in the complex series of cellular and molecular events which make up the allergic response [3-6]. The basophil has often been described as a circulating mast cell, but, in reality, although both cells are intimately associated with the pathogenesis of asthma they are derived from distinct lineages [7], and fulfil a range of different functions. Mast cells constitute a uniquely heterogeneous family of cells with marked differences between mast cells from different tissues and species. These differences mean that it is often impossible to extrapolate from a model system to the human, and serious gaps remain in our understanding of the molecular organization of human mast cells and basophils. Throughout this review, we have tried to emphasize the role of human lung mast cells and basophils, and have only drawn on examples from rodent mast cells or tumour cell lines when no studies have been carried out on the corresponding human cells. Though mast cells are uniquely associated with the initiation of the allergic response, there is accumulating evidence to implicate these cells in a broader range of pathophyisological conditions.

\section{Origin and differentiation}

The most detailed studies of mast cell origin and differentiation have come from the rodent [8-10]. Here there are clear differences between mucosal and connective tissue mast cells and there are comparatively few circulating basophils. In addition, two distinct mast cell deficient strains of mouse have been identified, and have made an invaluable contribution to elucidating the key role of stem cell factor (SCF) in mast cell differentiation [11-15]. In the human, the situation is less clear. The distinctions between mast cells from different tissues are much less clear cut $[16,17]$, and whilst basophils constitute less than $1 \%$ of all circulating leucocytes [18], they undoubtedly contribute to different allergic conditions [19-21].

Initial studies in the murine system demonstrated that progenitors from the bone marrow could be induced to differentiate to mast cells by the addition of supernatants from stimulated T-cells [22]. Further investigations have shown that the majority of this activity can be ascribed to the synergistic actions of interleukins 3, 4, 9 and 10 (IL-3, IL-4, IL-9 and IL-10) [23-26]. IL-3 is the only one of these to induce mast cell growth and differentiation in the absence of the other cytokines. IL4, IL-9 and IL-10 will all synergize with IL-3 [27].

Despite the evidence that IL-3 is a potent mast cell growth factor in the murine system, mature human lung mast cells do not express IL-3 receptors [28], and there is no evidence to suggest that IL-3 has any effect on mature human mast cells [29]. SCF appears to be the predominant determinant of the earliest stages of human mast cell differentiation [30, 31], and mature mast cells retain the receptor for SCF [32]. In vivo, SCF is probably derived from the fibroblasts, and fibroblasts are widely 
used as feeder layers to maintain mature mast cells in culture [33], or to study differentiation of mast cells [34]. Co-culture of cord blood cells with $3 \mathrm{~T} 3$ fibroblasts leads to the development of mast cells expressing both tryptase and chymase and resembling skin mast cells [35, 36], whilst suspension culture with SCF produces mast cells which express only tryptase and resemble immature lung mast cells [36, 37]. This suggests that either fibroblasts secrete additional cytokines, or that the manner in which the SCF is presented is critical in regulating expression of the chymase gene. The presence of additional cytokines or environmental factors appears to be critical for regulating the final stages of mast cell differentiation, as mast cells maintained in suspension with SCF fail to become fully mature mast cells [37]. Morphologically, these cells have an immature nucleus, lipid bodies and, though they have substantial numbers of granules, they lack the regular patterns associated with mature mast cells, although they express high affinity IgE receptors and their granules contain histamine [37-39]. Cultured mast cells sensitized with $\mathrm{IgE}$ will undergo degranulation and synthesize prostaglandins and leukotrienes following crosslinking of the IgE, suggesting that many of the signal transduction mechanisms are in place and the cells are fully functional.

Intriguingly, whilst IL-4 acts as a co-factor for IL-3 in inducing mast cell growth and differentiation in the murine system, the available evidence suggests that IL4 antagonizes the effects of stem cell factor in human mast cell progenitor cells [38, 40].

The exact pathway for basophil differentiation is not fully understood. However, there is strong evidence to implicate IL-3 in the growth and maturation of basophils. Addition of IL-3 to cultures of cord blood, foetal liver and bone marrow-derived cells increases the number both of basophils and eosinophils [41-44]. There is some evidence that granulocyte macrophage colony-stimulating factor (GM-CSF) and interleukin-5 (IL-5) can substitute for IL-3, although these effects are probably transduced via the IL-3 receptor $[45,46]$. There is also evidence that leucocyte interferon may inhibit IL-3-dependent differentiation of basophils from bone marrow precursor cells [47].

Differentiation of mast cells and basophils is intimately linked to the expression of FceRI and development of histamine containing granules, which together distinguish these cells from other haemopoetic cells. The synthesis of the FceRI $\alpha$-chain appears to be one of the earliest events involved preceding the formation of metachromatic granules [48, 49]. Evidence from the murine system suggests that IL-9 may have a role in promoting the expression of the FceRI $\alpha$-chain [27], though it is not clear if it has a similar role in the human system.

\section{Morphology}

Human mast cells are variable in shape with a round nucleus. The cell membrane has multiple folds and projections (fig. 1). The cytoplasm contains numerous granules, mitochondria and rough endoplasmic reticulum. There are few ribosomes evident, and the Golgi zone is not prominent [50-54]. Human lung mast cell granules show heterogeneous patterns of lattices, scrolls and whirls. These substructural patterns may occur within one cell, and frequently a single granule contains evidence of more than one type of pattern $[53,54]$. These patterns are thought to result from the packing of the proteoglycans and proteolytic enzymes, and there is evidence that granules rich in swirls are associated with the presence of tryptase [55]. In addition to numerous granules, lung mast cells frequently contain variable numbers of electron-dense lipid bodies [56]. Activation of the mast cells results in swelling of granules, their fusion to form tortuous degranulation channels, which

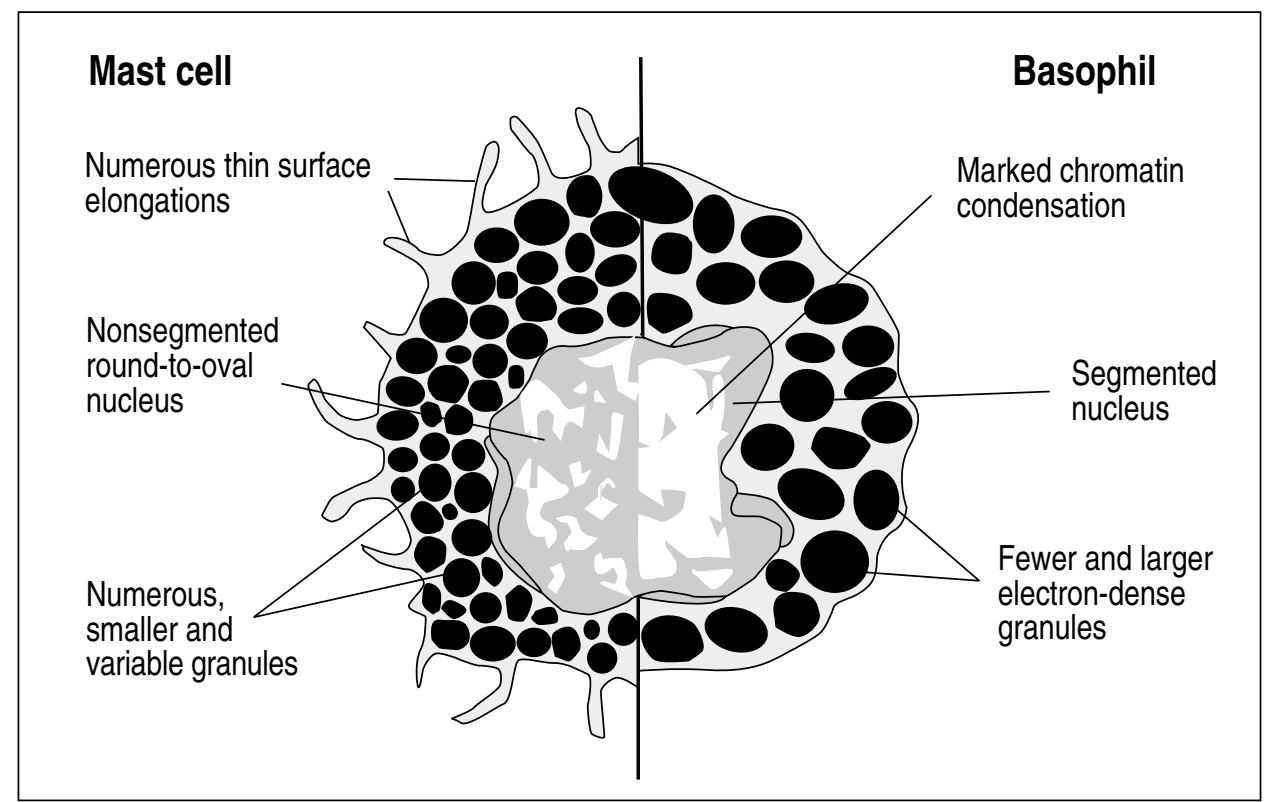

Fig. 1. - Comparison of the morphological features of mature human basophils and human mast cells. 
eventually fuse with the plasma membrane to allow the granule contents to diffuse away [56].

The peripheral blood basophil is typically a round cell with a few short blunt projections, but no evidence of the long surface projections of the lung mast cell [54, 57]. The nucleus shows marked chromatin condensation, is lobular, and more than one lobe may be seen in some sections (fig. 1). The cytoplasm has numerous granules, with visible mitochondria and few ribosomes. In comparison to mast cells, basophils contain fewer and larger granules which are electron-dense, and lack many of the distinct patterns associated with the mast cell $[54,58]$. Crosslinking of cell surface IgE typically leads to movement of the granules to the cell surface and their fusion with the cell membrane. Unlike the lung mast cell, their is little evidence for the fusion of granules or the formation of degranulation channels [54, 57-59].

\section{Membrane receptors and surface markers}

Both mast cells and basophils express a wide range of surface antigens and receptors (fig. 2). These can be divided into those found on resting cells and those which are expressed only on activated cells. For convenience, the receptors on resting and activated cells will be considered separately. It is also worth noting that most of the studies which have examined cell surface receptors on mast cells and basophils have utilized fluorescent cell-sorting, and it is possible that this technique may fail to detect small numbers $(<1,000)$ of receptors on the cell surface. Negative results may also result from "hidden" antigens or the expression of alternative epitopes.

\section{Resting cells - common receptors}

High affinity IgE receptor. Both mast cells and basophils express high affinity $\operatorname{IgE}$ receptors (FceRI) in varying numbers, depending, in part, on the allergic status of the donor. The FceRI has been cloned and sequenced, and consists of a tetrameric complex of $\alpha-\beta$ - and two $\gamma$ chains [60-62]. The $\alpha$-chain has a long extracellular domain, which contains two immunoglobulin-like loops. The evidence suggests that the second of these loops binds a region of the $\mathrm{C} \varepsilon 3$ on the $\mathrm{IgE}$ molecule, and that the IgE molecule takes up a convex shape on the cell surface [63]. The $\alpha$-chain has only a short cytoplasmic tail, and the association with the $\beta \gamma_{2}$ complex appears to be required for expression of the $\alpha$-chain [61]. The $\beta \gamma_{2}$ complex is also thought to have an important role in signal transduction, and both $\beta$ - and $\gamma$-chains contain tyrosine and serine or threonine residues, which are rapidly phosphorylated following IgE crosslinking [64]. The $\beta$-chain has four transmembrane spanning regions and shares some homology with CD20, a known ion channel [65]. Intriguingly, whilst the sequences of the $\alpha$ - and $\gamma$-chains show substantial interspecies homology, there are marked differences between the $\beta$-chains of human and rodent. The two $\gamma$-chains, with their long cytoplasmic domains, closely resemble the $\zeta$-chains of the T-cell receptor in size and molecular architecture $[62,66]$. This homology allows substitution of one dimer for the other in receptor expression. The expression of the FceRI was once thought to be a unique characteristic of mast cells and basophils; however, in the past 2 yrs this receptor has been identified on the Langerhans' cell [67]. More recently, it has been shown that the FceRI is expressed on eosinophils of certain hypereosinophilic donors [68], though it is not clear if this extends to the eosinophils of normal or asthmatic patients.

CD40 and CD40 ligand. Recent studies suggest that mast cells and basophils both express a protein with homology to members of the nerve growth factor and tumour necrosis factor $(\mathrm{NGF} / \mathrm{TNF}-\alpha)$ receptor family.

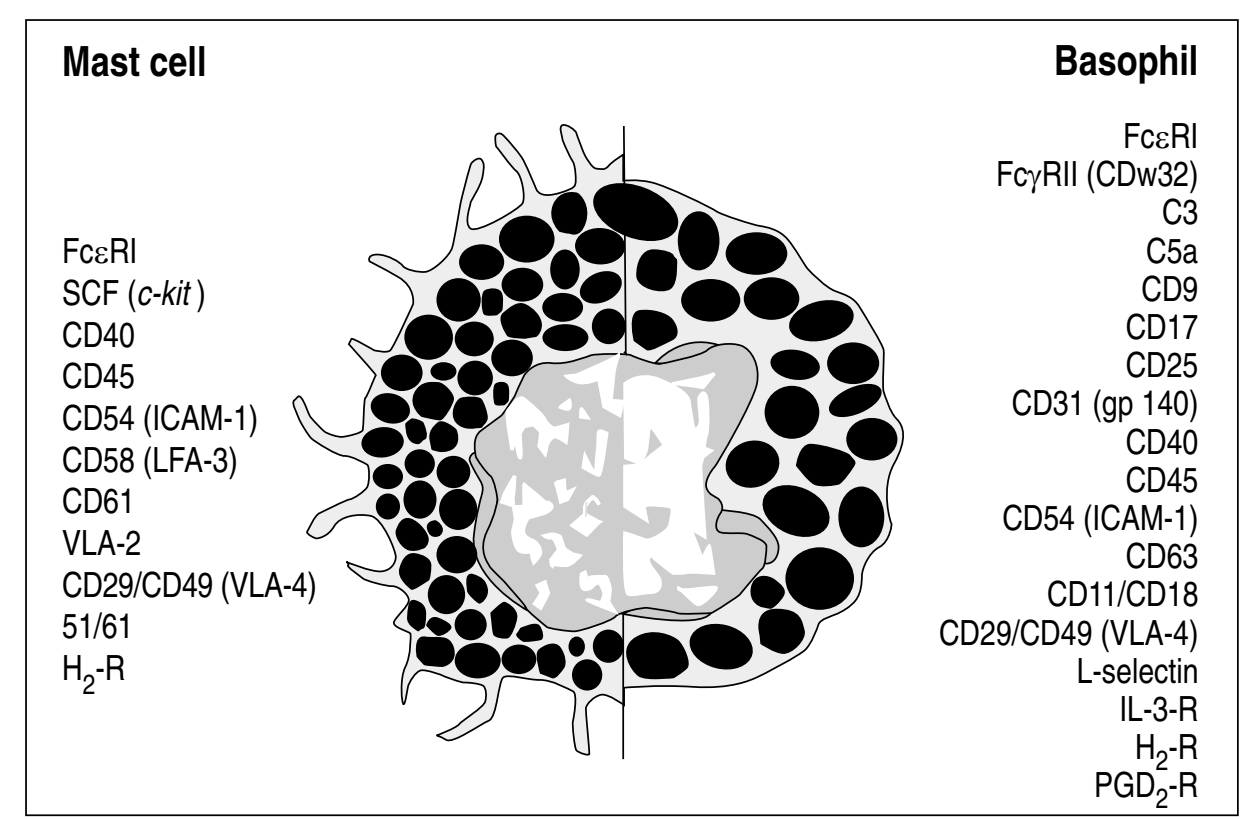

Fig. 2. - Surface antigen expression on human mast cells and basophils. SCF: stem cell factor; ICAM-1: intercellular adhesion molecule-1; LFA3: leucocyte function associated antigen-3; VLA-2 and VLA-4: very late activation antigens 2 and 4; $\mathrm{H}_{2}-\mathrm{R}$ : histamine receptor; IL-3-R: interleukin-3 receptor; $\mathrm{PGD}_{2}-\mathrm{R}$ : prostaglandin $\mathrm{D}_{2}$ receptor. 
This also acts as a receptor for CD40, and is known as CD40 ligand [69]. CD40 is found on the surface of the $\mathrm{B}$-cells, and the interaction between CD40 and its ligand combine with IL-4 to stimulate the B-cell to switch to IgE synthesis. This report suggests that the class switch to IgE could occur in situ, in the antigen-challenged lung rather than the peripheral lymph nodes, and supports the hypothesis that the microenvironment within the tissues is likely to be critical in regulating the progression to chronic disease. Basophils also express CD40, which is a member of a diverse family of proteins, which include receptors for nerve growth factor and tumour necrosis factor $[70,71]$.

Integrins. Quiescent basophils express low levels of the $\beta_{2}$-integrin complex, CD11/CD18, which is rapidly upregulated following IgE crosslinking [72]. They also express the $\beta_{1}$-integrins, CD29/CD49 family, and very late activation antigen-4/vascular cell adhesion molecule1 (VLA-4)/(VCAM-1) interaction contributes to basophil migration through the endothelium [73]. Unstimulated human lung mast cells express $\beta_{1}$ - and $\beta_{3}$-integrins, including very late activation antigen-2 (VLA-2), VLA4 and the vitronectin receptor, CD61 [74]. Lung mast cells and basophils both express low levels of CD54 (intercellular adhesion molecule-1 (ICAM-1)) [75, 76].

Receptors for histamine. Basophils and mast cells both possess a receptor for histamine $\left(\mathrm{H}_{2}\right)$. As for prostaglandin $D_{2}[77,78]$, this receptor is linked to the generation of cyclic adenosine monophosphate (cAMP), and act in an autocrine fashion to inhibit the release of histamine.

\section{Resting cells - other receptors}

Basophil receptors. In addition to the high affinity $\operatorname{IgE}$ receptor, human basophils express CDw32, the Fc $\gamma$ RII receptor for immunoglobulin G (IgG) [79]. Basophils, in common with many other leucocytes, also possess receptors for a range of different inflammatory stimuli, including the complement peptides, $\mathrm{C} 3 \mathrm{a}$ and $\mathrm{C} 5 \mathrm{a}$, and bacterial products, such as f-methionyl-formyl-leucylphenyalanine $[80,81]$. The f-met peptide and the complement peptides will both initiate histamine release in basophils from a wide range of donors, though the complement peptides are "incomplete" stimuli and fail to initiate leukotriene release unless the basophils have been primed $[81,82]$. In contrast, IgG triggers degranulation in only a small percentage of donors [83], and it is not clear if the levels of $\mathrm{IgG}$ required could be attained in vivo. Basophils also possess a receptor for prostaglandin $\mathrm{D}_{2}\left(\mathrm{PGD}_{2}\right)[77,78]$, which is linked to the generation of cAMP and may act in an autocrine negative feedback fashion.

In common with other leucocytes, the basophil expresses the common leucocyte antigen, CD45, and the other markers CD17 and CD9 [75, 84, 85]. Basophils also constitutively express the part of the interleukin-2 (IL2) receptor, $\mathrm{CD} 25$ [85], although there is no evidence so far that the multi-chain IL-2 receptor is expressed, or that IL-2 initiates a functional response. Basophils have
IL-3 receptors, which appear to modulate the actions of several other related cytokines, through the common $\beta$ chain of the IL-3 receptor. The basophil specific marker recognized by the antibody Bsp-1 [86] is now known to be found at low levels on several other leucocytes (Bochner BS, personal communication).

Mast cell receptors. In contrast to the basophil, lung mast cell do not express receptors for f-met peptide or the complement peptides. Whilst skin mast cells are able to release histamine in response to a range of polycationic stimuli $[87,88]$, possibly via direct interaction with the $\mathrm{G}$ protein [89], lung mast cells fail to respond to any of these agents. Despite IL-3 being a potent growth factor for murine mast cells, human lung mast cells do not have receptors for IL-3 [29]. Lung mast cells do, however, possess receptors for SCF, and this has been shown to modulate the responses of mature mast cells [90], in addition to regulating mast cell growth and differentiation.

Lung mast cells express substantial numbers of CD45 receptors [75, 91]. This marker, originally known as leucocyte common antigen, supports a haemopoetic origin for mast cells. It is now known to have tyrosine phosphatase activity [92, 93], and may have a critical role in regulating cell responses [94].

\section{Stimulated cells}

Integrins. Activation of basophils leads to a rapid increase in the expression of CD11b/CD18, which together with the VLA-4 complex (CD29/CD49d) regulates adhesion to the endothelium and the recruitment of basophils into the tissues $[72,73,95]$. In common with other inflammatory leucocytes, activation of human basophils leads to an apparent decrease in the expression of L-selectin. The co-ordinated expression of various adhesion molecules is likely to be critical for the accumulation of basophils in the tissues following antigen challenge. Although mast cell distribution is altered during chronic inflammation, this occurs over extended periods and may reflect altered patterns of mast cell differentiation as well as alterations in adhesion molecule expression. Indeed, activation of mast cells may well lead to a decrease in the expression or the affinity of the adhesion molecules, allowing the mast cell to migrate towards the area of inflammation [95-97].

Other markers. Activation of basophils leads to the expression of the platelet granule protein, CD63, on their cell surface in an all-or-nothing manner [98]. Human lung mast cells have been reported to express increased levels of CD54 following an overnight incubation with IL-4 [99].

\section{Cellular constituents and products}

\section{Preformed mediators}

Histamine. The granules both of mast cells and basophils contain substantial amounts of histamine, which is one 
Table 1. - Major currently known mast cell- and basophil-derived mediators

\begin{tabular}{|c|c|c|}
\hline & Mast cell & Basophil \\
\hline Lipids & $\begin{array}{l}\text { Platelet-activating factor (PAF) } \\
\text { Leukotriene } \mathrm{C}_{4} \\
\text { Leukotriene } \mathrm{B}_{4} \\
\text { Prostaglandin } \mathrm{D}_{2} \\
\text { Prostaglandin } \mathrm{E}_{2} \\
\text { Thromboxane } \mathrm{A}_{2}\end{array}$ & $\begin{array}{l}\text { Platelet-activating factor (PAF) } \\
\text { Leukotriene } \mathrm{C}_{4}\end{array}$ \\
\hline Enzymes & $\begin{array}{l}\text { Hexoaminopeptidase } \\
\text { Arylsulphatase B } \\
\beta \text {-glucuronidase } \\
\beta \text {-galactosidase } \\
\text { Carboxypeptidase } \\
\text { Tryptase } \\
\text { Chymase } \\
\text { Kininogenase } \\
\text { Superoxide dismutase }\end{array}$ & \\
\hline Cytokines & $\begin{array}{l}\text { Interleukin-4? } \\
\text { Interleukin-5* } \\
\text { Interleukin- } 6^{*} \\
\text { Tumour necrosis factor- } \alpha\end{array}$ & Interleukin-4 \\
\hline Others & $\begin{array}{l}\text { Histamine } \\
\text { Proteoglycan (heparin) }\end{array}$ & $\begin{array}{l}\text { Histamine } \\
\text { Proteoglycan (chondroitin } \\
4 \text { and } 6 \text { sulphates) }\end{array}$ \\
\hline
\end{tabular}

of the distinguishing features of these cells (table 1). In the case of the basophil, there is approximately $1 \mathrm{pg}$ of histamine in each cell [100], whilst lung mast cells contain 3-4 pg.cell ${ }^{-1}$ [101]. Histamine is synthesized from histidine within the Golgi zone, and stored within the granules as a complex with proteoglycans. Mast cells from other species have an uptake mechanism for amines of a similar size, such as serotonin (5-HT), allowing them to store the 5-HT in their granules, a process that does not occur in human mast cells. Histamine is a potent inflammatory agent responsible for many of the symptoms of the immediate allergic response, including bronchoconstriction, vasodilation, mucus secretion and oedema. However, histamine is rapidly broken down in the body and its duration of action is limited to minutes.

Proteolytic enzymes. The proteolytic enzymes of the mast cell (table 1) have not been as intensely studied as histamine. However, they have a range of possible activities, which could be relevant to pulmonary disease. Tryptase has the capacity to cleave a number of proteins, which could contribute to the pathophysiology of the inflammatory response, including complement proteins and kinins [102, 103]. Recently, there has been evidence that mast cell proteases can inactivate cytokines, though chymase appears to be more potent than tryptase (Walls AF, personal communication). Tryptase has been shown to be a potent mitogen for fibroblasts, which may contribute to the tissue remodelling seen in chronic inflammatory conditions, such as asthma [104]. Tryptase may also activate leucocytes, increasing chemotaxis and priming the cells to a subsequent stimulus (Walls AF, personal communication). However, human mast cell tryptase is unable to trigger degranulation or priming in human basophils [105].

Tryptase is stored in the granule as the active enzyme, and does not require further processing to acquire full proteolytic activity [106]. It is thought that the combination of the low $\mathrm{pH}$ within the granule and the presence of histamine regulate its activity [107]. Once released, tryptase rapidly dissociates from the active, tetrameric form of the enzyme to yield monomers and the heparin core. These monomers lack proteolytic activity but have a relatively long half-life [108], and their detection in plasma or bronchoalveolar lavage (BAL) provides a useful measure of lung mast cell activation in vivo.

Proteoglycans. Both histamine and proteolytic enzymes are bound to proteoglycans within the granules. These give the granules their crystalline structure and lead to the formation of areas of the granule with regular patterns of scrolls, gratings and lattices. The significance of these structures is unclear, with granules containing one or more type of arrangement. In the murine system, there are clear distinctions between the proteoglycans of mast cells from the mucosa and connective tissue. Mucosal mast cells express predominantly chondroitin sulphate $b$, whilst the connective tissue mast cells contain heparin [109]. However, the evidence available suggests that human lung mast cells contain a mixture of both heparin and chondroitin sulphates [110]. In contrast to the mast cell, human basophils contain little or no tryptase, and the majority of the proteoglycans are chondroitin sulphates [111]. 
Cytokines. The presence of stored cytokines within the mast cell granules is still being explored, and there are clear differences between the human mast cells and the more extensively characterized murine system $[112,113]$. There is evidence that the release of TNF- $\alpha$ from mouse mast cells is derived from two distinct sources, both preformed and newly synthesized, with distinct kinetics of release [114]. There is immunohistochemical evidence for TNF- $\alpha$, IL-4, IL-5 and interleukin-6 (IL-6) in the granules of human mast cells $[115,116]$, which may be available for release following IgE cross-linking. It has been reported that IL-4 can be detected in mast cell supernatants [116], but this typically occurs in less than $15 \%$ of the preparations and does not appear to be related to the extent of histamine release. Recent studies with human lung mast cells suggest that they are unable to induce the class switch to IgE in B-lymphocytes in the absence of exogenous IL-4 [69], suggesting that, unlike the basophil, they do not synthesize sufficient quantities of IL-4 to regulate IgE production.

\section{Newly synthesized mediators}

Lipids. Crosslinking of IgE on the human lung mast cells leads to the synthesis of substantial amounts both of $\mathrm{PGD}_{2}$ and leukotriene $\mathrm{C}_{4}\left(\mathrm{LTC}_{4}\right)[117,120]$. Both these mediators are potent bronchoconstrictors with half-lives of several minutes in plasma. The breakdown of $\mathrm{LTC}_{4}$ to leukotriene $\mathrm{D}_{4}\left(\mathrm{LTD}_{4}\right)$ and leukotriene $\mathrm{E}_{4}$ $\left(\mathrm{LTE}_{4}\right)$ yields two further potent bronchoconstrictors, and a combination of these three agents is thought to account for the majority of the bronchoconstriction following antigen challenge. Lung mast cells produce smaller amounts of $\mathrm{LTB}_{4}$, thromboxane $\mathrm{B}_{2}\left(\mathrm{TxB}_{2}\right)$ and prostaglan$\operatorname{din} \mathrm{E}_{2}\left(\mathrm{PGE}_{2}\right)$ [119], all of which may contribute to the inflammation which characterizes the late phase response. IgE-dependent activation of human basophils leads to the synthesis of substantial quantities of $\mathrm{LTC}_{4}$ but no prostaglandin $[118,119]$. The presence of histamine, $\mathrm{LTC}_{4}$ but not $\mathrm{PGD}_{2}$ during a late phase response [19-21] has been used as evidence that it is the basophil and not the mast cell which is responsible for the recurrence of symptoms. Platelet-activating factor (PAF) is another newly synthesized lipid mediator with the ability to influence a range of different aspects of inflammation. PAF and its 1-acyl analogue, 1-acyl-2-acetyl-sn-glycerol3-phosphocholine, are synthesized both by human lung mast cells and basophils $[121,122)$. PAF has been shown to initiate basophil degranulation under certain conditions [123], though there is evidence that its actions are indirect and require the presence of neutrophils [124]. The release of PAF either from mast cells or basophils amplifies the inflammatory response, leading to the activation and recruitment of neutrophils and eosinophils.

Cytokines. In most cell types, including T-cells, cell activation leads to the de novo synthesis of cytokines, which are rapidly released and not stored within the cell. In the basophil, IL-4 is newly synthesized over a period of hours following IgE crosslinking [125], and basophils primed with IL-3 can release substantial amounts of IL-
4 [126], making these cells an important cellular source of this cytokine (table 1). All of the available evidence suggests that the IL-4 is newly synthesized following IgE receptor crosslinking and release takes place over 4-8 h. Measurement of cytokine messenger ribonucleic acid (mRNA) by in situ hybridization has shown that up to $10 \%$ of the IL-5 positive cells in nasal biopsies are mast cells [127]. Studies of cytokine production and release by human lung mast cells are technically difficult because of the requirement for large numbers of highly purified cells, and our current state of understanding of these important mediators is still incomplete. It seems likely that the next 2-3 yrs will see an increase in the number of cytokines produced by human mast cells and our understanding of the mechanisms involved.

\section{Heterogeneity}

\section{Mast cell heterogeneity}

Mast cells from different species are heterogeneous, and this extends to mast cells isolated from different tissue locations within a single species. The heterogeneity encompasses size, cell surface receptors, granularity, granule contents, newly synthesized mediators, cytokine profile, and may extend as far as basic cell biochemistry [128]. Mast cells are often classified on the basis of their proteases, containing either tryptase $\left(\mathrm{MC}_{\mathrm{T}}\right)$ or tryptase and chymase $\left(\mathrm{MC}_{\mathrm{TC}}\right)$. In the murine system, this classification defines two distinct populations of cells from mucosa and connective tissue. However, in the human, most tissues contain a mixture of the two cell types and the differences between the mucosal and connective tissue mast cells are much less well-defined. Thus, in the human, mast cells are likely to be influenced by the local environment within the tissue, and alterations during chronic disease may well influence the number and type of mast cells. Pulmonary mast cells are predominantly of the $\mathrm{MC}_{\mathrm{T}}$ phenotype, with approximately $15 \%$ of the cells being $\mathrm{MC}_{\mathrm{TC}}$ [129]. Mast cells recovered in BAL resemble the tissue mast cell, as they are mostly $\mathrm{MC}_{\mathrm{T}}$ although they are smaller and much more responsive to IgE than their counterparts in the lung [130], and may contain a substantial number of basophils [131].

Unlike mast cells from skin, which respond to a range of different secretagogues, there is no evidence that lung mast cells from either dispersed tissue or BAL release histamine when stimulated with neuropeptides, complement peptides or diverse polycationic stimuli, such as compound 48/80, codeine and morphine [80, 81]. SCF initiates degranulation in skin mast cells [132], and primes lung mast cells to a subsequent IgE-mediated challenge [83], but fails to trigger histamine release in dispersed lung mast cells [83, 132].

\section{Differences between mast cells and basophils}

Whilst basophils have historically been regarded as the peripheral blood counterparts of the tissue mast cell, we 
Table 2. - Major currently known mast cell- and basophil activation and priming factors

\begin{tabular}{lll}
\hline & Mast cell & Basophil \\
\hline Lipids & Platelet-activating factor (PAF) & Platelet-activating factor (PAF) \\
& Leukotriene $\mathrm{C}_{4}$ & Leukotriene $\mathrm{C}_{4}$ \\
& Leukotriene $\mathrm{B}_{4}$ & \\
& Prostaglandin $\mathrm{D}_{2}$ & \\
Proteins & Antigen & Antigen \\
& Anti-IgE & Anti-IgE \\
& Anti-IgG & Anti-IgG \\
& & Complement protein 3a* \\
& Major basic protein & Complement protein 5 \\
& Eosinophil peroxidase & Major basic protein \\
& & Eosinophil peroxidase \\
& & Pepstatin A \\
& SCF & Protein A (S. aureus) \\
Cytokines & & Interleukin-3 \\
& & Interleukin- $8^{*}$ \\
& & SCF \\
Others & Ionomycin & \\
& & Ionomycin \\
& & Phorbol esters \\
& & Formyl-methionine peptides \\
& & Hyperosmolarity \\
& &
\end{tabular}

*: partial agonist. IgE: immunoglobulin E; IgE: immunoglobulin G; SCF: stem cell factor.

now know that they are derived from distinct lineages and comprise unique cell types. Basophils contain less histamine, respond to a much wider range of stimuli, express a distinct profile of cell surface markers (fig. 2), and release a different profile of lipid mediators (table 2). They appear to fulfil different roles in the pathogenesis of the allergic response. The tissue bound mast cells provide the initial release of inflammatory mediators in response to antigen. The effects of these mediators are then amplified by the influx of leucocytes, especially eosinophils and basophils, during the late phase response, which are responsible for many of the symptoms of chronic inflammation.

\section{Activation and priming}

\section{Activation}

A number of basophil and mast cell-activating mediators have been described (table 2). For instance, the crosslinking of IgE on the mast cell surface initiates a complex series of biochemical events, which mediate granule extrusion and the synthesis of lipid mediators. The signal transduction mechanisms which lead from the crosslinking of $\operatorname{IgE}$ on the cell surface to granule extrusion are not fully understood. Studies using rodent mast cells have shown that the $\operatorname{IgE}$ receptor is associated with one or more tyrosine kinases [133], and an increase in tyrosine phosphorylation is one of the earliest detectable events, occurring within $5 \mathrm{~s}$ of IgE crosslinking [64, 134]. Both in human lung mast cells and basophils, the evidence for the involvement of tyrosine kinases is based on pharmacological evidence. Some inhibitors of tyrosine kinases will selectively inhibit IgE-dependent histamine release, though this is not always complete and cannot be regarded as definitive [135]. Intriguingly, lung mast cells and basophils show distinct inhibition profiles, supporting the hypothesis that the IgE receptor may be linked to different tyrosine kinases in these two cells.

Evidence from the rodent mast cell systems suggest that the activation of a receptor-linked tyrosine kinase appears to modulate a wide range of other proteins, including $\gamma$-subunits of the IgE receptor [64, 134], phospholipase $C \gamma 1[136,137]$, the vav proto-oncogene product [138], and pp125FAK [139, 140], a tyrosine kinase found in focal adhesions in fibroblasts and other cells. There is strong evidence to support a role for phosphorylation of phospholipase $\mathrm{C} \gamma$, which could in turn generate Ins $(\mathrm{P})_{3}$ and diacylglycerol (DAG), leading to an increase in intracellular calcium ions $\left(\left[\mathrm{Ca}^{2+}\right]_{\mathrm{i}}\right)$.

Activation of human lung mast cells leads to the mobilization of $\left[\mathrm{Ca}^{2+}\right]_{\mathrm{i}}$ and an influx of extracellular $\mathrm{Ca}^{2+}$, and the magnitude of this $\left[\mathrm{Ca}^{2+}\right]_{i}$ signal correlates with the extent of degranulation [141]. There is an increase in $\left[\mathrm{Ca}^{2+}\right]_{\mathrm{i}}$ in activated human basophils, which also accurately predicts the release of histamine; however, the increase in $\left[\mathrm{Ca}^{2+}\right]_{i}$ is typically much less than that seen for an equivalent histamine release in the lung mast cell [142]. This would suggest that a second, synergistic signal contributes to exocytotic pathways in basophils. Phorbol ester is able to trigger extensive degranulation without mobilizing $\left[\mathrm{Ca}^{2+}\right]_{\mathrm{i}}$, suggesting that $\left[\mathrm{Ca}^{2+}\right]_{\mathrm{i}}$ is not an essential component of the exocytotic pathway in these cells [142]. Careful analysis of the $\left[\mathrm{Ca}^{2+}\right]_{\mathrm{i}}$ signals 
in human mast cells and basophils has shown that, whilst individual human basophils undergo periodic oscillations in cytosolic $\left[\mathrm{Ca}^{2+}\right]_{\mathrm{i}}$, there are no such fluctuations in human mast cells [143], supporting the hypothesis that the differences between these two cell types extend to biochemical signals within the cell.

Although the IgE receptor has seven transmembrane spanning regions, extensive investigations into guanosine triphosphate (GTP)-binding proteins failed to identify a receptor associated GTP-binding protein. Pertussis toxin failed to modify IgE-induced degranulation in the human basophil, despite completely ablating the response to the complement peptide, C5a and f-met peptide [144]. Whilst similar studies in the human lung mast cell lack the positive controls provided by $\mathrm{C} 5 \mathrm{a}$ and $\mathrm{f}$ met peptide in the basophil, they provide no evidence for a pertussis toxin sensitive GTP-binding protein in human lung mast cells. Studies in the rat mast cell suggest that the final stages of exocytosis are regulated by a GTP-binding protein, $\mathrm{G}_{\mathrm{E}}[145,146]$. However, this protein has not been isolated either in human or rodent mast cells and the exact role of this protein in the $\mathrm{IgE}$ signal transduction cascade remains unclear.

\section{Priming}

The activation or priming of mast cells and basophils by cytokines is thought to play an important role in the pathophysiology of asthma. There is evidence that mast cells from areas of active inflammation [147], including BAL mast cells isolated during the late phase response in asthmatic patients [148], are primed and respond to lower concentrations of anti-IgE. This suggests that factors within the inflammatory environment are able to modulate the mast cell responses priming the cells. Elucidating the mechanisms responsible for this mast cell priming would clearly be of interest, and yet most studies of cytokine priming have focused on the ability of cytokines to increase IgE-dependent histamine release, rather than an increase in sensitivity to $\operatorname{IgE}$ crosslinking. Extensive surveys of the interactions between cytokines and human mast cells have, with the exception of SCF [83], failed to identify any cytokines which modulate mast cell releasability. SCF enhanced IgEdependent activation of human lung mast cells, without initiating mediator release alone [83]. The concentrations of SCF required to obtain maximal priming are between $1-10 \mathrm{ng} \cdot \mathrm{ml}^{-1}$, values close to those identified in plasma [132], suggesting that physiological concentrations of SCF could well be relevant to mast cell releasability.

The human basophil presents a different picture, and a number of cytokines which may be relevant to inflammation are able to prime these cells and increase the response to a subsequent IgE-dependent stimulus [132, 149-153]. Probably, the most extensively investigated cytokine is IL-3, and many of the other cytokines which modify basophil responses do so via the $\beta$-chain of the IL-3 receptor $[45,46]$. In addition to initiating degranulation in a subset of donors, IL-3 is a potent upregulator of IgE-dependent mediator release. It also acts to "complete" several partial basophil agonists, such as C3a and interleukin-8 (IL-8), by triggering the release of $\mathrm{LTC}_{4}$ in addition to degranulation $[154,155]$. Despite expressing substantial amounts of CD25 on their cell surface, there is little indication that administration of IL-2 alters the maturation or responsiveness of basophils [153].

The signal transduction mechanisms responsible for priming represent a logical target for therapeutic intervention, since the cells of asthmatic donors appear to be primed in vivo. However, these studies are complex and, to date, very few investigators have focused on these events. Since many of the agents known to induce priming act via tyrosine kinases, this pathway is the obvious candidate for investigation. However, recent investigations in human basophils have shown that IL-3 priming involves a five- to tenfold increase in the amount of arachidonic acid liberated during exposure to C5a [156]. This highlights the role of enzymes, such as phospholipase $A_{2}$ or phospholipase $\mathrm{D}$, in cytokine priming. The remaining evidence for the signal transduction pathways utilized during priming is pharmacological, and the complexity of the studies makes it difficult to obtain definitive evidence. However, in our hands, inhibitors of tyrosine kinases are unable to modify either IL-3-dependent release or IL-3 priming, suggesting that cytokine priming signals may well be distinct from those used in cytokineinduced growth and differentiation pathways [157].

\section{Interactions within the tissues}

The majority of the investigations which have provided the information about mast cells and mast cell responses described in this review have been carried out on either purified cells or under conditions where mast cells are selectively activated. However, it is important to keep in mind that, in vivo, mast cells and basophils are in close proximity to a range of different cells and the interactions between these cells may well be critical for regulating the progress of allergic disease. Some of the potential cell-cell interactions have been alluded to earlier, and so only the most important are summarized here.

\section{Fibroblasts}

The interactions between mast cells and fibroblasts are probably the most critical of the cell-cell interactions. Several studies have demonstrated that murine mast cells can be maintained in culture by a fibroblast feeder layer $[158,159]$. Progenitor cells treated in this way differentiate into mature mast cells, whilst cells maintained in suspension culture with SCF fail to fully mature [38]. This may reflect the production of additional cytokines by the fibroblasts or the presentation of the growth factors on the cell surface. Mast cells dispersed from human lung can also be maintained in culture for extended periods on fibroblast feeder layers [160, 161].

\section{T-lymphocytes}

The development of mucosal mast cells is intimately linked to the production of cytokines by $\mathrm{TH}_{2}$ cells, 
described earlier. Human immunodeficiency virus (HIV) patients and others with T-cell deficiencies have decreased $\mathrm{MC}_{\mathrm{T}}$ levels, which may contribute to the development of opportunistic infections [162]. The role of T-cellderived cytokines in regulating mast cell motility and responsiveness remains unclear. Mast cells isolated from areas of active inflammation are "primed", releasing more mediators following challenge [147, 148]. There may also be an increase in the number of mast cells [163], though this is not a consistent finding in asthma [164]. These areas also contain substantial numbers of activated T-cells, but the precise relationship between $\mathrm{T}$ cell activation and changes in mast cell response is not clear.

\section{B-lymphocytes}

Mature B-cells are an important source of IL-10 [165], which can combine with IL-4 to provide a signal for IL3 independent mast cell growth and differentiation in the murine system. As with many other aspects of rodent mast cell differentiation, it is not clear whether similar mechanisms operate in the human system. The recent observation that human lung mast cells and basophils both express CD40L [69] and could influence the class switch to IgE in mature B-cells is perhaps a clearer indication of the importance of mast cell/B-cell interactions and the ability of the mast cell to regulate its own environment.

\section{Eosinophils}

The activation of tissue mast cells is one of the earliest events in the allergic response, and the release of chemotactic agents may be responsible for the influx of leucocytes, especially eosinophils. Many of these chemotactic agents are lipids, including PAF and $\mathrm{LTB}_{4}$, and are capable of attracting neutrophils as well as eosinophils [166-168]. Reports that mast cells produced chemotactic peptides which were specific for eosinophils have proved to be unfounded [168].

A number of studies have demonstrated that eosinophil derived major basic protein (MBP), eosinophil cationic protein (ECP) and eosinophil peroxidase (EPO) induce noncytolytic histamine release both from human basophils and mast cells (for review see [169]). In addition, it has been shown that EPO binds to the negatively charged mast cell granule to form a complex that retains toxic activity to bacteria and tumour cells when supplemented with $\mathrm{H}_{2} \mathrm{O}_{2}$ and a halide. Since EPO in the presence of $\mathrm{H}_{2} \mathrm{O}_{2}$ and a halide can initiate mast cell granule release, it is conceivable that mast cells and eosinophils may act synergistically to improve host defence in infectious and malignant conditions [170]. On the other hand, mast cell granules released during inflammation may contribute to the tissue irritation caused by other eosinophil proteins.

\section{Interactions with the extracellular matrix}

Within the tissues, the mast cells and infiltrating leucocytes are held in a complex three-dimensional matrix of neighbouring cells and extracellular matrix proteins. These interactions are regulated by the expression of integrins on the cell surface, which function as receptors directly linking the extracellular environment to the cytoskeleton [171, 172]. Recent evidence suggests that clustering of the integrins can generate a range of cell responses, including alterations in gene expression [173], and regulation of second messengers [174-176]. Amongst the wide variety of kinases and regulatory enzymes which may be upregulated by integrin clustering are several which could, potentially, modulate IgEdependent signal transduction in human mast cells and basophils [176-180]. However, studies of lung mast cell function are typically carried out on enzymatically dispersed cells in solution, and attempts to mimic the types of cell-cell and cell-matrix interactions using tissue fragments present problems of diffusion and accurate assessment of cell responses. We have recently used monoclonal antibodies to CD29 and CD49d followed by an F(ab') fragment of rabbit anti-mouse IgG to cluster the integrins on the surface of lung mast cells and basophils. Clustering of either CD29 or CD49d leads to a small but significant release of histamine in basophils of asthmatic donors, yet fails to activate basophils of atopic and nonatopic subjects [181]. This suggests that alterations in the extracellular matrix which occur during tissue remodelling could initiate degranulation in susceptible individuals. Clustering of the integrins also modulates the response to a subsequent IgE-dependent challenge both in lung mast cells and basophils, regardless of the atopic status of the donor. These experiments highlight the importance of the extracellular matrix and the microenvironment on the responsiveness of the resident cells, and suggest that further investigations into this area are needed.

\section{Role in human disease}

\section{Allergic diseases}

The crosslinking of $\operatorname{IgE}$ by antigen, leading to mast cell degranulation and the release of a range of inflammatory mediators, is widely acknowledged to be one of the initial steps in the allergic response [182, 183]. For instance, mast cell degranulation was found in the bronchial mucosa of asthmatic subjects [184, 185], and in nasal mucosa [183] of allergic subjects with or without allergen exposure. The presence of mast cell activation, even in mild asthma, is further supported by raised levels of mast cell-derived mediators in BAL [21, 186]. Mast cell mediators regulate the recruitment and activation of a wide range of other inflammatory cells. However, during the chronic inflammation which characterizes asthma, the lung contains a complex mixture of inflammatory mediators, cytokines and activated cells, and the microenvironment is quite distinct. Mast cells are now, themselves, subject to regulation by cytokines and other mediators produced by a wide range of activated cells, and even the alterations in the extracellular matrix may have a 
profound effect on mast cell function. These changes may well contribute to mast cell priming, and a subsequent exposure to allergen will lead to an amplified response and exacerbation of the underlying condition. Whilst the mast cell has a less central role in this model of allergic inflammation, and the scientific focus now encompasses a range of other cells, understanding and regulating mast cell activation may well still provide the key to treatment of asthma.

\section{Pulmonary fibrosis}

Large numbers of mast cells can be found in the lungs of patients with fibrotic lung disease, usually clustered around the thickened areas of the alveolar septa and in close proximity to abnormal epithelial cells [51]. The relationship between the mast cell and the development of fibrosis is not clear, though there are clear morphological differences between mast cells in fibrotic tissue and normal controls [51]. Mast cells may be recruited to the areas of the lung where tissue repair is occurring and may contribute to the repair process [187]. Alternatively, the abnormal environment within the fibrotic areas may increase the growth and differentiation of mast cells and they may exert influence on the progression of the disease, possibly through the mitogenic activity of tryptase [104] or histamine [188].

\section{Tumours}

The relationship between mast cells and tumours is undoubtedly complex. Immunohistochemical evidence suggests that both mast cells and basophils can accumulate around tumours [189-191], though it is not clear if this is detrimental or beneficial to the tumour. Activation of mast cells leads to a local inflammatory response, recruitment of immune cells, and may be able to contribute to recognition and destruction of a tumour [192, 193]. However, mast cell degranulation also releases substantial amounts of heparin, which promotes angiogenesis [194], and there is evidence that mast cells may contribute to the vascularization of tumours [195], or the direct proliferation of tumour cells [196]. Histamine may also promote endothelial cell proliferation and mast cell proteases are capable of degrading the extracellular matrix to promote the formation of neovascular sprouts. As for eosinophils [169], understanding the role of mast cells in tumour biology may well provide new insights into the treatment of primary tumours and the prevention of metastases.

\section{Parasitosis}

In the rodent, infection with a range of helminths leads to mastocytosis and the production of IgE. The pattern of cytokines induced by helminth infection is characteristic of the $\mathrm{Th}_{2}$ response $[169,197]$, and leads to an increase mainly in mucosal or $\mathrm{M}_{\mathrm{TC}}$ mast cells. This apparently reflects the production of substantial amounts of IL-3, IL-4 and IL-9 by the activated T-cells [198-200]. In man, production of IgE directed against schistosomes confers a significant level of protection against a subsequent infection. However, the production of $\operatorname{IgE}$ and the activation of T-cells will influence many other cells, including those which express the low affinity $\mathrm{IgE}$ receptor, and these may have a more direct role in expelling parasites than mast cells and basophils.

\section{Therapeutic intervention}

Selective intervention in the process of mast cell degranulation offers an important therapeutic tool in regulating the progression of asthma and allergic disease. However, whilst many drugs currently available have been shown to affect mast cell and basophil degranulation in vitro they are rarely selective. Furthermore, in many cases, there is only a tenuous relationship between the actions of a drug on mast cell degranulation and its effect on the development of allergic symptoms. Frequently, the concentration of the drug required to inhibit histamine release in vitro exceeds by orders of magnitude the concentrations which are likely to accumulate in vivo. Several cromoglycate analogues were found to be potent inhibitors of mast cell histamine release and yet failed to match the anti-allergic actions of the parent compound. The reasons for these discrepancies are likely to be complex, but as our understanding of mast cell biology continues to accumulate it is to be anticipated that we will gain insights which will provide new therapeutic modalities in the treatment of mast cell related diseases.

\section{References}

1. Riley JF, West GB. Presence of histamine in tissue mast cells. J Physiol (Lond) 1953; 120: 528-537.

2. Rosenthal S, Schwartz JH, Cannelos GP. Basophilic chronic granulocytic leukaemia with hyperhistaminaemia. Br J Haematol 1977: 36: 367-372.

3. Schwartz LB, Austen KF. Structure and function of the chemical mediators of mast cells. Prog Allergy 1984; 34: 1-141.

4. Austen KF, Orange RP. Bronchial asthma: the possible role of the chemical mediators of immediate hypersensitivity in the pathogenesis of subacute chronic disease. Am Rev Respir Dis 1975; 112: 423-436.

5. Lichtenstein LM, Osler AG. Studies on the mechanisms of hypersensitivity phenomena. IX. Histamine release from human leukocytes by ragweed pollen antigen. J Exp Med 1964; 120: 507-530.

6. Wasserman SI, Marquardt DL. Anaphylaxis. In: Middleton E Jr, Reed CE, Ellis EF, Adkinson NF Jr, Yuninger JW, eds. Allergy: Principles and Practice. Third ed. St. Louis, CV Mosby, 1988; pp. 1365-1376.

7. Valent P, Ashman LK, Hinterberger W, et al. Mast cell typing: demonstration of a distinct hematopoietic cell type and evidence for immunophenotypic relationship to mononuclear phagocytes. Blood 1989; 7: 17781785. 
8. Galli SJ. New insights into the riddle of the mast cells. Microenvironmental regulation of mast cell development and phenotypic heterogeneity. Lab Invest 1990; 62: 5-33.

9. Lee TDG, Swieter M, Befus AD. Heterogeneity in mast cell populations. Clin Immunol Rev 1986; 4: 143-199.

10. Metcalfe DD, Kaliner MA, Donlon MA. The mast cell. Crtical Reviews in Immunology 1981; 23-74.

11. Jarboe DL, Huff TF. The mast cell committed progenitor. II. W/Wv mice do not make cell-committed progenitors and $\mathrm{Sl} / \mathrm{Sld}$ fibroblasts do not support development of normal mast cell committed progenitors. J Immunol 1989; 142: 2418-2433.

12. Galli SJ, Geissler EN, Wershil BK, Gordon JR, Tsai M, Hammel I. Insights into mast cell development and function derived from analyses of mice carrying mutations at beige, W.c kit or Sl.SCF(c-kit ligand) loci. In: Kaliner MA, Metcalfe DD, eds. The Role of the Mast Cell in Health and Disease. New York, Marcel Dekker, 1992; pp. 129-202.

13. Kitamura Y, Go S, Hantanaka S. Decrease of mast cells in $\mathrm{W} / \mathrm{Wv}$ mice and their increase by bone marrow transplantation. Nature 1981; 291: 159-160.

14. Galli SJ Kitamura Y. Genetically mast cell deficient $\mathrm{W} / \mathrm{Wv}$ and $\mathrm{Sl} / \mathrm{Sld}$ mice: their values for the analysis of mast cells in biological responses in vivo. Am J Pathol 1987; 127: 191-198.

15. Nakano T, Sonoda T, Hayashi C, et al. Fate of bone marrow-derived cultured mast cells after intracutaneous, intraperitoneal and intravenous transfer into genetically deficient $\mathrm{W} / \mathrm{Wv}$ mice: evidence that cultured mast cells can give rise to both connective tissue type and mucosal mast cells. J Exp Med 1985; 162: 1025-1043.

16. Fox CC, Dvorak AM, Peters SP, Kagey-Sobotka A, Lichtenstein LM. Isolation and characterization of human intestinal mucosal mast cells. J Immunol 1985; 135: 483-491.

17. Irani AA, Schechter NM, Craig SS, DeBlois MD, Schwartz LB. Two types of human mast cells that have distinct neutral protease composition. Proc Natl Acad Sci USA 1986; 83: 4464-4469.

18. Juhlin L. Basophil leukocyte differential in blood and bone marrow. Acta Haemat 1963; 29: 89-95.

19. Lichtenstein LM, Bochner BS. Role of basophils in asthma. Ann NY Acad Sci 1991; 629: 48-61.

20. Bascom RB, Wachs M, Naclerio RM, Pipkorn U, Galli SJ, Lichtenstein LM. Basophil influx occurs after nasal antigen challenge: effects of topical corticosteroid pretreatment. J Allergy Clin Immunol 1988; 81: 580589.

21. Liu MC, Hubbard WC, Proud D, et al. Immediate and late inflammatory responses to ragweed antigen challenge of the peripheral airways in allergic asthmatics: cellular, mediator and permeability changes. Am Rev Respir Dis 1991; 144: 51-58.

22. Nabel G, Galli SJ, Dvorak AM, Dvorak HF, Cantor H. Inducer T-lymphocytes synthesize a factor that stimulates proliferation of cloned mast cells. Science 1981; 212: 332-334.

23. Ihle $\mathrm{JH}$, Keller J, Oroszlan S, et al. Biological properties of homogeneous interleukin-3. I. Demonstration of WEHI-3 growth factor activity, mast cell growth activity, stimulating factor activity and histamine producing activity. J Immunol 1983; 131: 282-287.

24. Mossman T, Bond MW, Coffman RL, Ohara J, Paul WE. T-cell and mast cell lines respond to B-cell stimulatory factor 1. Proc Natl Acad Sci USA 1986; 83: 5654-5658.
25. Williams DE, Morrissey PJ, Mochizuki DY et al. T-cell growth factor $\mathrm{P} 40$ promotes proliferation of myeloid cell lines and enhances erythroid burst formation by normal murine bone marrow cells in vitro. Blood 1990; 76: 906-911.

26. Hamaguchi Y, Kanakura Y, Fujita J, et al. Interleukin4 as an essential factor for the in vitro clonal growth of murine connective tissue type mast cells. J Exp Med 1987; 165: 268-273.

27. Renauld J-C, Houssiau F, Louahed J, Vink A, Van Snick J, Uyttenhove C. Interleukin-9. Adv Immunol 1993; 54: 79-97.

28. Valent P, Besemer J, Sillaber C, et al. Failure to detect IL-3 binding sites on human mast cells. J Immunol 1990; 145: 3422-3427.

29. Okayama Y, Church MK. IL-3 primes and evokes histamine release from human basophils but not mast cells. Int Arch Allergy Appl Immunol 1992; 99: 343-345.

30. Galli SJ, Zsebo KM, Geissler EN. The kit ligand, stem cell factor. Adv Immunol 1994; 51: 1-96.

31. Denburg JA. Basophil and mast cell lineages in vitro and in vivo. Blood 1992; 79: 846-860.

32. Lerner NB, Nocka KH, Cole SR, et al. Monoclonal antibody YB5. B8 identifies the human $c$-kit protein product. Blood 1991; 77: 1876-1883.

33. Levi-Schaffer F, Austen KF, Caulfield JP, Hein A, Gravellese PM, Stevens RL. Co-culture of human lungderived mast cells with mouse 3T3 fibroblasts: morphology and IgE-mediated release of histamine, prostaglandin $\mathrm{D}_{2}$ and leukotrienes. J Immunol 1987; 139: 494-500.

34. Irani AA, Craig SS, Nilsson G, Ishizaka T, Schwartz LB. Characterization of human mast cells developed from fetal liver cells co-cultured with murine 3T3 fibroblasts. Immunology 1992; 77: 136-143.

35. Furitsu T, Saito H, Dvorak AM, et al. Development of human mast cells in vitro. Proc Natl Acad Sci USA 1993; 86: 10039-10043.

36. Dvorak AM, Furitsu T, Kissell-Rainville S, Ishizaka T. Ultrastructural identification of human mast cells resembling skin mast cells stimulated to develop in long-term human cord blood mononuclear cells cultured with 3T3 murine skin fibroblasts. J Leukocyte Biol 1992; 51: 557-569.

37. Mitsui M, Ruritsu T, Dvorak AM, et al. Development of human mast cells from umbilical cord blood cells by recombinant human and murine c-kit ligand. Proc Natl Acad Sci USA 1993; 90: 735-739.

38. Ishizaka T, Mitsui H, Yanagida M, Miura T, Dvorak AM. Development of human mast cells from their progenitors. Curr Opin Immunol 1993; 5: 937-943.

39. Dvorak AM, Mitisui H, Ishizaka T. Human and murine recombinant $c$-kit ligands support the development of human mast cells from umbilical cord blood cells: ultrastructural identification. Int Arch Allergy Appl Immunol 1993; 101: 247-253.

40. Sillaber C, Strobl H, Bevec D, et al. IL-4 regulates $c$ kit proto-oncogene product expression in human mast and myeloid progenitor cells. J Immunol 1991; 147: 4224-4228.

41. Seldin CD, Caulfield JP, Hein A, et al. Biochemical and phenotypic characterization of human basophilic cells derived from dispersed fetal liver with murine Tcell factors. J Immunol 1986; 136: 2222-2230.

42. Kirshenbaum AS, Goff JP, Dreskin SC, Irani AM, Schwartz LB, Metcalfe DD. IL-3-dependent growth of basophil like cells and mast-cells from human bone marrow. $J$ Immunol 1989; 142: 2424-2429. 
43. Dvorak AM, Saito H, Estrella P, Kissell S, Arai N, Ishizaka T. Ultrastructure of eosinophils and basophils stimulated to develop in human cord blood mononuclear cell culture containing recombinant human interleukin-5 or interleukin-3. Lab Invest 1989; 61: 116-130.

44. Kirshenbaum AS, Goff JP, Kessler SW, Mican JM, Zsebo KM, Metcalfe DD. Effect of IL-3 and stem cell factor on the appearance of human basophils and mast cells from CD34+ pluripotent progenitor cells. J Immunol 1992; 148: 772-777.

45. Lopez AF, Eglington JM, Lyons AB, et al. Human interleukin-3 inhibits the binding of granulocyte macrophage-stimulating factor and interleukin-5 to basophils and strongly enhance their functional activity. $J$ Cell Physiol 1990; 145: 69-78.

46. Miyajima A, Kitamura T, Harada N, Yokota T, Arai K. Cytokine receptors and signal transduction. Ann Rev Immunol 1992; 10: 295-331.

47. Sillaber C, Geissler K, Eher R, et al. Type beta transforming growth factors promote IL-3-dependent differentiation of human basophils but inhibit IL-3-dependent differentiation of human eosinophils. Blood 1992; 80: 634-641.

48. Thompson HL, Metcalfe DD, Kinet J-P. Early expression of high affinity receptors for IgE during differentiation of mouse mast cells and human basophils. $J$ Clin Invest 1990; 85: 1227-1232.

49. Rottem M, Barbieri S, Kinet J-P, Metcalfe DD. Kinetics of the appearance of FceRI-bearing cells in interleukin3-dependent mouse bone marrow dependent cultures: correlation with histamine content and mast cell maturation. Blood 1991; 79: 972-980.

50. Dvorak AM. The fine structure of human basophils and mast cells. In: Holgate ST, ed. Mast Cells, Mediators and Disease. Kluwer, Academic Publishers. 1988; pp. 29-97.

51. Kawanami O, Ferrans VJ, Fulmer JD, Crystal RG Ultrastructure of pulmonary mast cells in patients with fibrotic lung disorders. Lab Invest 1979; 40: 717-734.

52. Dvorak AM, Schulman ES, Peters SP, et al. Immunoglobulin E mediated degranulation of isolated lung mast cells. Lab Invest 1985; 53: 45-56.

53. Kobayasi T, Mitgard K, Asboe-Hansen G. Ultrastructure of human mast cell granules. J Ultrastruct Res 1968; 23: $153-165$.

54. Dvorak AM. Basophils and mast cells: piecemeal degranulation in situ and ex vivo: a possible mechanism for cytokine-induced function in disease. In: Coffey RG, ed. Granulocyte Responses to Cytokines. Immunology Series 57. New York, Marcel Dekker, 1992; pp. 169-299.

55. Irani AA, Schwartz LB. Neutral proteases as indicators of human mast cell heterogeneity. Monogr Allergy 1990; 27: 146-162.

56. Dvorak AM, Dvorak HF, Peters SP, et al. Lipid bodies: cytoplasmic organelles important to arachidonic acid metabolism in macrophages and mast cells. J Immunol 1984; 131: 2965-2976.

57. Dvorak AM, Newball HH, Dvorak HF, Lichtenstein LM. Antigen-induced IgE-dependent degranulation of human basophils. Lab Invest 1980; 43: 126-139.

58. Galli SJ, Dvorak AM, Dvorak HF. Biology of basophils and mast cells: morphologic insights into their biology, secretory patterns and function. Prog Allergy 1984; 34: 1-118.

59. Hastie R, Levy A, Weiss L. The antigen-induced degranulation of basophil leukocytes from atopic subjects studied by electron microscopy. Lab Invest 1982; 36: 173-182.

60. Blank U, Ra C, Miller L, White K, Metzger H, Kinet J-P. Complete structure and expression in transfected cells of the high affinity IgE receptor. Nature 1989; 337: 187-189.

61. Kochon J, Pettine LF, Hakimi J, Kishi K, Kinet J-P. Isolation of the gene for the alpha-subunit of the human high affinity $\operatorname{IgE}$ receptor. Nucleic Acids Res 1988; 16: 35-84.

62. Kinet J-P, Blank U, Ra C, White K, Metzger H, Kochan $\mathrm{J}$. Isolation and characterization of cDNAs coding for the $\beta$-subunit of the high affinity receptor for immunoglobulin E. Proc Natl Acad Sci USA 1988; 85: 64836487.

63. Zheng Y, Shopes B, Holowka D, Baird B. Conformations of IgE bound to its receptor, FceRI, and in solution. Biochemistry 1991; 30: 9125-9132.

64. Paolini R, Jouvin M-H, Kinet J-P. Phosphorylation and dephosphorylation of the high affinity receptor for $\operatorname{IgE}$ immediately after receptor engagement and disengagement. Nature 1991; 353: 855-858.

65. Bubien JK, Zhou LJ, Bell PD, Frizzell RA, Tedder TF. Transfection of the CD20 surface molecule into ectopic cell types generates a $\mathrm{Ca}^{2+}$ conductance found constitutively in B-lymphocytes. J Cell Biol 1992; 121: $1121-1132$.

66. Howard FD, Rodewald H-R, Kinet J-P, Reinherz EL. CD3 $\zeta$ subunit can substitute for the $\gamma$-subunit of the Fce receptor type I in the assembly and functional expression of the high affinity $\mathrm{IgE}$ receptor: evidence for interreceptor complementation. Proc Natl Acad Sci USA 1990; 87: 7015-7019.

67. Bieber T, de la Salle H, Wollenberg A, et al. Human epidermal Langerhans' cells express the high affinity receptor for immunoglobulin E. J Exp Med 1992; 175: $1285-1290$.

68. Gounni AS, Lamkhioued B, Ochai K, et al. High affinity $\mathrm{IgE}$ receptor on eosinophils is involved in defences against parasites. Nature 1994; 367: 183-186.

69. Gauchat J-F, Henchoz S, Mazzei G, et al. Induction of human IgE synthesis in B-cells by mast cells and basophils. Nature 1993; 365: 340-343.

70. Schall TM, Lewis K, Koller K, et al. Molecular cloning and expression of a receptor for human tumor necrosis factor. Cell 1990; 61: 361-365.

71. Smith C, Davis T, Anderson D, et al. A receptor for tumour necrosis factor defines an unusual family of cellular and viral proteins. Science 1990; 248: 10191023.

72. Bochner BS, McGlashan DW, Marcotte GV, Schleimer RP. IgE-dependent regulation of human basophil adherence to vascular endothelium. J Immunol 1989; 142: 3180-3186.

73. Bochner BS, Luscinskas FW, Gimbrone MA, et al. Adhesion of human basophils, eosinophils and neutrophils to interleukin-1 activated human vascular endothelial cells: contributions of endothelial cell adhesion molecules. J Exp Med 1991; 173: 1553-1557.

74. Guo C-B, Kagey-Sobotka A, Lichtenstein LM, Bochner BS. Immunotyping and functional analysis of purified human uterine mast cells. Blood 1992; 79: 708-712.

75. Valent P, Bettelheim P. Cell surface structures on human basophils and mast cells: biochemical and functional characterization. Adv Immunol 1992; 52: 333-423.

76. Bochner BS, McKelvey AA, Schleimer RP, Hildreth JEK, MacGlashan Jr. Flow cytometric methods for the 
analysis of human basophil surface antigens and viability. J Immunol Methods 1989; 125: 265-271.

77. Lichtenstein LM, Gillespie E. Inhibition of histamine release by histamine controlled by $\mathrm{H}_{2}$ receptor. Nature 1973; 244: 287-288.

78. Virgolini I, Li S, Sillaber C, et al. Characterization of prostaglandin binding sites expressed on human basophils. Evidence for a prostaglandin $\mathrm{E}_{1}, \mathrm{I}_{2}$ and $\mathrm{D}_{2}$ receptor. J Biol Chem 1992; 267: 12700-12708.

79. Stain C, Stockinger H, Scharf M. Human blood basophils display a unique phenotype including activation linked membrane structures. Blood 1987; 70: 18721879.

80. Hook WA, Schiffman E, Aawanikumar S, Siragainian RP. Histamine release by chemotactic formyl methionine containing peptides. J Immunol 1976; 117: 594596.

81. Schulman ES, Post TJ, Henson PM, Giclas PC. Differential effects of the complement peptides C5a and C5a des Arg on human basophil and lung mast cell histamine release. J Clin Invest 1988; 81: 918-923.

82. Kurimoto Y, deWeck AL, Dahinden CA. Interleukin-3 dependent mediator release in basophils triggered by C5a. J Exp Med 1989; 170: 467-479.

83. Poulsen LK, Shahl Skov P, Mosbech H, Weeke B. Role of $\mathrm{IgG}_{4}$ in histamine release from human basophil leukocytes. Int Arch Allergy Appl Immunol 1988; 86: 383388.

84. Valent $\mathrm{P}, \mathrm{Ashman} \mathrm{LH}$, Hinterberger $\mathrm{W}$, et al. Interleukin3 is a differentiation factor for human basophils. Blood 1989; 73: 1763-1769.

85. Stockinger H, Valent $\mathrm{P}$, Majdic O, Bettelheim P, Knapp W. Human blood basophils synthesize IL-2 binding sites. Blood 1990; 75: 1820-1826.

86. Bodger MP, Mounsey GL, Nelson J, Fitzgerald PH. A monoclonal antibody reacting with human basophils. Blood 1987; 69: 1414-1418.

87. Benyon CR, Robinson C, Church MK. Human skin mast cells: their dispersion, purification and secretory characteristics. J Immunol 1987; 138: 861-867.

88. Lawrence ID, Warner JA, Hubbard WC, Kagey-Sobotka A, Lichtenstein LM. Purification and characterization of human skin mast cells: evidence for human mast cell heterogeneity. J Immunol 1987; 139: 3062-3067.

89. Mousli M, Bronner C, Bochaert J, Roust B, Landry Y. Interaction of substance $\mathrm{P}$, compound $48 / 80$ and mastoparan with the $\alpha$-subunit $\mathrm{C}$ terminal of $\mathrm{G}$ protein. Immunol Lett 1990; 25: 355-358.

90. Bischoff ST, Dahinden CA. c-kit ligand: a unique potentiator of mediator release by human lung mast cells. J Exp Med 1992; 175: 237-244.

91. Reshef A, MacGlashan DW Jr. Immunogold probe for the light microscopic phenotyping of human mast cells and basophils. J Immunol Meth 1989; 99: 213-219.

92. Fischer EH, Charbonneau H, Tonks NK. Protein tyrosine phosphatases: a diverse family of intracellular and transmembrane enzymes. Science 1991; 253: 401406.

93. Weaver CT, Pingel JT, Nelson JO, Thomas ML. CD45: a transmembrane protein tyrosine phosphatase involved in the transduction of antigenic signals. Biochem Soc Trans 1992; 20: 169-173.

94. Hook WA, Berenstein EH, Zinsser FU, Fischler C, Siraganian RP. Monoclonal antibodies to the leukocyte common antigen (CD45) inhibit IgE-mediated histamine release from human basophils. J Immunol 1991; 147: 2670-2676.
95. Hamawy MM, Mergenhagan SE, Siraganian RP. Adhesion molecules as regulators of mast cell and basophil function. Immunol Today 1994; 15: 62-66.

96. Thompson HL, Burbelo PD, Yamada Y, Kleinman HK, Metcalfe DD. Mast cells chemotaxis to laminin with enhancement after IgE-mediated activation. J Immunol 1989; 143: 4188-4192.

97. Thompson HL, Metcalfe DD. Murine mast cells attach to and migrate on laminin, fibronectin- and matrigelcoated surfaces in response to FceRI-mediated signals. Clin Exp Allergy 1993; 23: 270-275.

98. Knol EF, Mul FPJ, Jansen H, Calafat J, Roos D. Monitoring human basophil activation via CD63 monoclonal antibody 435. J Allergy Clin Immunol 1991; 88: 328338.

99. Valent $\mathrm{P}$, Bevec $\mathrm{D}$, Maurer D, et al. IL-4 promotes expression of mast cell macrophage ICAM-1 antigen. Proc Natl Acad Sci USA 1991; 88: 3339-3342.

100. MacGlashan DW Jr, Lichtenstein LM. The purification of human basophils. J Immunol 1980; 124: 25192521.

101. Schulman ES, MacGlashan DW Jr, Peters SP, Schleimer RP, Newball HH, Lichtenstein LM. Human lung mast cells: purification and characterization. J Immunol 1982; 129: 2662-2668.

102. Proud D, Siekerski ES, Bailey GS. Identification of human lung mast cell kininogenase as tryptase and relevance of tryptase kininogenase activity. Biochem Pharmacol 1988; 37: 1473-1478.

103. Mizutani H, Schechter N, Lazerus G, Black RA, Kupper TS. Rapid and specific conversion of precursor interleukin$1 \beta$ to an active IL-1 species by human mast cell chymase. J Exp Med 1991; 174: 821-825.

104. Ruoss SJ, Hartmann T, Caughey GH. Mast cell tryptase is a mitogen for cultured fibroblasts. J Clin Invest 1991; 88: 493-499.

105. Warner JA, Proud D. Human lung mast cell tryptase fails to activate human basophils. J Allergy Clin Immunol 1994; 93: 196.

106. Schwartz LB, Bradford TR. Regulation of tryptase from human lung mast cells by heparin: stabilisation of the active tetramer. J Biol Chem 1986; 261: 73727379.

107. Alter SC, Schwartz LB. Effect of histamine and divalent cations on the activity and stability of tryptase from human mast cells. Biochim Biophys Acta 1989; 991: 426-430.

108. Schwartz LB, Yunginger JW, Miller J, Bokhari R, Dull D. The time course of appearance and disappearance of human mast cell tryptase in the circulation after anaphalaxis. J Clin Invest 1989; 83: 1551-1555.

109. Stevens RL, Lee TDG, Seldin CD, Austen KF, Befus $\mathrm{AD}$, Bienenstock J. Intestinal mucosal mast cells from rats infected with Nippostrongylus brasiliensis contain protease resistant chondroitin sulfate di-b proteoglycans. J Immunol 1986; 137: 291-295.

110. Stevens RL, Fox CC, Lichtenstein LM, Austen KF. Identification of chondroitin sulfate $\mathrm{E}$ proteoglycans and heparin proteoglycans in the secretory granules of human lung mast cells. Proc Natl Acad Sci USA 1988; 85: 2284-2287.

111. Metcalfe DD, Blande CE, Wasserman SI. Biochemi$\mathrm{cal}$ and functional characterization of proteoglycans isolated from basophils of patients with chronic myelogenous leukemia. J Immunol 1984; 132: 1943-1959.

112. Plaut M, Peirce JH, Watson CJ, Hanley-Hide J, Nordan RP, Paul WE. Mast cell lines produce lymphokines in 
response to crosslinkage of Fc\&RI or to calcium ionophores. Nature 1989; 339: 64-67.

113. Burd PR, Rogers HW, Gordon JR, et al. Interleukin-3dependent and independent mast cells stimulated with IgE and antigen express multiple cytokines. J Exp Med 1989; 170: 245-257.

114. Gordon JR, Galli SJ. Release of both preformed and newly synthesized tumour necrosis factor- $\alpha /$ cachectin by mouse mast cells stimulated via the FceRI. A mechanism for the sustained action of mast cell derived TNF- $\alpha$ during IgE-dependent biological responses. J Exp Med 1991; 174: 103-107.

115. Walsh LJ, Trinchieri G, Waldorf HA, Whitaker D, Murphy GF. Human dermal cells contain and release tumor necrosis factor- $\alpha$, which induces endothelial leukocyte adhesion molecule-1. Proc Natl Acad Sci USA 1991; 88: 4220-4224.

116. Bradding $\mathrm{P}$, Feather $\mathrm{IH}$, Howarth $\mathrm{PH}$, et al. Interleukin4 is localized to and released from human lung mast cells. J Exp Med 1992; 176: 1381-1387.

117. Lewis RA, Soter NA, Diamond PT, Austen KF, Oates JA, Roberts LJ. Prostaglandin $\mathrm{D}_{2}$ generation after activation of rat and human mast cells with anti-IgE. $J$ Immunol 1983; 129: 1627-1631.

118. MacGlashan DW Jr, Schleimer RP, Peters SP, et al. Generation of leukotrienes by purified human lung mast cells. J Clin Invest 1982; 70: 2747-2751.

119. Peters SP, MacGlashan DW Jr, Schulman ES, et al. Arachidonic acid metabolism in purified human lung mast cells. J Immunol 1984; 132: 1972-1979.

120. Warner JA, Peters SP, Lichtenstein LM, Stevenson HC Miller PJ, MacGlashan DW Jr. Differential release of mediators from human basophils: differences in arachidonic acid metabolism following activation by unrelated stimuli. J Leukocyte Biol 1989; 45: 558-565.

121. Triggiani M, Hubbard WC, Chilton FH. Synthesis of 1acyl-2-acetyl-sn-glycero-3-phosphocholine by an enriched preparation of human lung mast cells. J Immunol 1990; 144: 4773-4479.

122. Triggiani M, Schleimer RP, Warner JA, Chilton FH. Differential synthesis of 1-acyl-2-acetyl-sn-glycero3-phosphocholine and platelet-activating factor by inflammatory cells. J Immunol 1991; 147: 660-666.

123. Brunner T, de Weck AL, Dahinden CA. Platelet-activating factor induces mediator release by human basophils primed with interleukin-3, granulocyte colony-stimulating factor or interleukin-5. J Immunol 1991; 147: 237 242.

124. Columbo M, Casolaro V, Warner JA, MacGlashan DW Jr, Kagey-Sobotka A, Lichtenstein LM. The mechanism of mediator release from human basophils induced by platelet-activating factor. J Immunol 1990; 145: 3855-3661.

125. Schroeder JT, MacGlashan DW Jr, Kagey-Sobotka A, Lichtenstein LM. IgE-dependent IL-4 secretion by basophils in mixed leukocyte cultures. J Allergy Clin Immunol 1994; 93: 214.

126. Brunner T, Heusser CH, Dahinden CA. Human peripheral blood basophils primed by interleukin-3 produce IL-4 in response to immunoglobulin E receptor stimulation. J Exp Med 1993; 177: 605-611.

127. Corrigan CJ, Hamid Q, Kay AB. T-lymphocytes and the pathogenesis of bronchial asthma: studies using the techniques of in situ hybridization and polymerase chain reaction cDNA amplification. In: Holgate ST, Austen KF, Lichtenstein LM, Kay AB, eds. Asthma: Physiology, Immunopharmacology and Treatment. London, Academic Press, 1993; pp. 153-162.
128. Warner JA, MacGlashan DW Jr, Lichtenstein LM. Heterogeneity of human FceRI bearing cells. In: IgE, Mast Cells and the Allergic Response. Chichester, John Wiley and Sons Ltd, (Ciba Foundation Symposium 147), 1989; pp. 230-253.

129. Matin R, Tam EK, Nadel JA, Caughey GH. Distribution of chymase containing mast cells in human bronchi. J Histochem Cytochem 1992; 40: 669-674.

130. Pearce FL, Flint KC, Leung KBP. Some studies on human pulmonary mast cells obtained bronchoalveolar lavage and enzymatic dissociation of whole lung. Int Arch Allergy Appl Immunol 1987; 82: 507-512.

131. Guo C-B, Liu MC, Galli SJ, Bochner BS, Kagey-Sobotka A, Lichtenstein LM. Identification of IgE-bearing cells in the late phase response to antigen in the lung as basophils. Am J Respir Cell Mol Biol (In press).

132. Columbo M, Horowitz EM, Botana LM, et al. The human recombinant $c$-kit receptor ligand, rhSCF, induces mediator release from human cutaneous mast cells and enhances IgE-dependent mediator release from both human skin mast cells and peripheral blood basophils. $J$ Immunol 1992; 149: 599-608.

133. Eiseman E, Bolen JB. Engagement of high-affinity IgE receptor activates $\operatorname{src}$ protein-related tyrosine kinases. Nature 1992; 355: 78-80.

134. Benhamou J, Gutkind JS, Robbins KC, Siragainian RP. Tyrosine phosphorylation coupled to IgE receptor mediated signal transduction and histamine release. Proc Natl Acad Sci USA 1990; 87: 5327-5330.

135. Lavens SE, Peachell PT, Warner JA. Effect of tyrosine kinase inhibitors on histamine release from human lung mast cells and basophils. Am J Respir Cell Mol Biol 1992; 7: 637-644.

136. Li W, Deanin GG, Margolis B, Schlessinger J, Oliver JM. FceRI-mediated tyrosine phospharylation of multiple proteins, including phospholipase $\mathrm{C} \gamma 1$ and the receptor $\beta \gamma_{2}$ complex in RBL-2H3 rat basophilic leukemia cells. Mol Cell Biol 1992; 12: 3176-3182.

137. Park DJ, Min HK, Rhee SG. IgE-induced tyrosine phosphorylation of phospholipase $\mathrm{C} \gamma 1$ in rat basophilic leukemia cells. J Biol Chem 1991; 266: 24237-24240.

138. Margolis B, Hu P, Katzav S, et al. Tyrosine phosphorylation of the vav oncongene product, a potential transcriptional regular with SH2 and SH3 domains. Nature 1992; 356: 71-74.

139. Hamawy MM, Mergenhagen SE, Siragainian RP. Tyrosine phosphorylation of $\mathrm{pp} 125^{\mathrm{FAK}}$ by the aggregation of high affinity immunoglobulin $\mathrm{E}$ receptors requires cell adherence. J Biol Chem 1993; 268: 6851-6854.

140. Pfieffer JR, Oliver JM. Tyrosine kinase-dependent assembly of actin plaques linking FceRI crosslinking to increased cell substrate adhesion in RBL-2H3 tumor mast cells. J Immunol 1994; 152: 270-279.

141. MacGlashan DW Jr. Single cell analysis of $\mathrm{Ca}^{2+}$ changes in human lung mast cells: graded $v s$ all-or-nothing elevations after IgE-mediated stimulation. J Cell Biol 1989; 109: 123-131.

142. Warner JA, MacGlashan DW Jr. Signal transduction events in human basophils: a comparative study of the role of protein kinase $\mathrm{C}$ in basophils activated by antiIgE antibody and formyl-methionyl-leucyl-phenylalanine. J Immunol 1990; 145: 1897-1905.

143. MacGlashan DW Jr, Guo C-B. Oscillations in cytosolic calcium during IgE-mediated stimulation distinguish human basophils from human mast cells. J Immunol 1991; 147: 2259-2269.

144. Warner JA, Yancey KB, MacGlashan DW Jr. Effect of 
pertussis toxin on mediator release from human basophils. J Immunol 1987; 139: 161-165.

145. Cockroft S, Howell TW, Gomperts BD. Two G-proteins act in series to control stimulus-secretion coupling in mast cells: use of neomycin to distinguish between Gproteins controlling polyphosphoinositide phosphodiesterases and exocytosis. J Cell Biol 1987; 105: 27452750.

146. Gomperts BD. $\mathrm{G}_{\mathrm{E}}$ : a GTP-binding protein mediating exocytosis. Ann Rev Physiol 1990; 52: 591-607.

147. Fox CC, Lazenby AJ, Moore WC, Yardley JH, Bayless TM, Lichtenstein LM. Enhancement of human intestinal mast cell mediator release in active ulcerative colitis. Gastroenterology 1990; 99: 119-124.

148. Flint K, Leung KBP, Hudspith BN, Brostoff J, Pearce FL, Johnson NMcI. Bronchoalveolar mast cell in extrinsic asthma: a mechanism for the initiation of antigen specific bronchoconstriction. $B r J$ Med 1985; 291: 923-926.

149. Massey WA, Randall TR, Kagey-Sobotka A, et al. Recombinant interleukin- $1_{\alpha}$ and $1_{\beta}$ potentiate IgE-mediated histamine release from human basophils. J Immunol 1989; 143: 1875-1880.

150. Bischoff SC, Bruner T, De Weck AL, Dahinden CA. Interleukin-5 modified histamine release and leukotriene generation by basophils in response to diverse agonists. J Exp Med 1990; 172: 1577-1582.

151. Kuna P, Reddigari SR, Schall TJ, Rucinski D, Sadick M, Kaplan AP. Characterization of the human basophil response to cytokines, growth factors, and histamine releasing factors of the intercrine/chemokine family. $J$ Immunol 1993; 150: 1932-1943.

152. Massey WA, Randall TC, Kagey-Sobotka A, et al. Recombinant human IL- $1 \alpha$ and $\beta$ potentiate IgE-mediated histamine release from human basophils. J Immunol 1989; 143: 1875-1880.

153. Alam R, Welter JD, Forsythe PA, Lett-Brown M, Grant JA. Comparative effect of recombinant IL-1, -2, -3, - 4 and -6 , IFN- $\gamma$, granulocyte macrophage colony-stimulating factor, tumor necrosis factor and histamine releasing factors on the secretion of histamine from human basophils. J Immunol 1989; 141: 3441-3436.

154. MacGlashan DW Jr, Warner JA. Stimulus-dependent leukotriene release from human basophils: a comparative study of C5a and f-met-leu-phe. J Leukocyte Biol 1991; 49: 29-40.

155. Dahinden CA, Kurimoto Y, de Weck AL, Lindley I, Dewald B, Baggiolini M. The neutrophil-activating peptide NAF/NAP-1 induced histamine and leukotriene release by interleukin-3 primed basophils. J Exp Med 1989; 170: 1787-1792.

156. Schleimer RP, Derse CP, Freidman BF, et al. Regulation of human basophil mediator release by cytokines. I. Interactions with anti-inflammatory steroids. J Immunol 1989; 143: 1310-1317.

157. Deacon LF, Lavens SE, Douglass JA, Holgate ST, Warner JA. Regulation of IgE and interleukin-3-induced histamine release from human basophils. J Allergy Clin Immunol 1993; 91: 257.

158. Levi-Schaffer F, Austen KF, Caulfield JP, Hein A, Bloes WF, Stevens RL. Fibroblasts maintain the phenotype and viability of the rat heparin containing mast cells in vitro. J Immunol 1985; 135: 3454-3461.

159. Katz HR, Daton ET, Levi-Schaffer F, Benson AC, Austen KF, Stevens RL. Co-culture of mouse IL-3dependent mast cells with $3 \mathrm{~T} 3$ fibroblasts stimulates synthesis of globopentaosylceramide (Forssman glycolipid) by fibroblasts and surface expression on both populations. J Immunol 1988; 140: 3090-3097.

160. Ginsburg H, Ben-Shahar D, Bar David E. Mast cells grow on fibroblast monolayers. Immunology 1982; 45: 371-377.

161. Dvorak AM, Furitsu T, Estrella P, Ishizaka T. Human lung derived mature mast cells cultured alone or with mouse 3 T3 fibroblasts maintain an ultrastructural phenotype different from that of human mast cells that develop from human cord blood cells cultured with 3T3 fibroblasts. Am J Pathol 1991; 139: 1309-1318.

162. Irani AM, Craig SS, DeBlois G, Elson CO, Schechter NM, Schwartz LB. Deficiency of the tryptase-positive, chymase-negative mast cell in the gastrointestinal mucosa of patients with defective T-lymphocyte function. J Immunol 1987; 138: 4381-4386.

163. Bentley AM, Jacobson MR, Cumberworth V, et al. Immunohistology of the nasal mucosa in seasonal allergic rhinitis: increases in activated eosinophils and epithelial mast cells. J Allergy Clin Immunol 1992; 89: 877-883.

164. Djukanovic R, Wilson JW, Britten KM, et al. Quantitation of mast cells and eosinophils in the bronchial mucosa of symptomatic atopic asthmatics and healthy control subjects using immunohistochemistry. Am Rev Respir Dis 1990; 142: 863-871.

165. O'Garra A, Stapleton G, Dhar V, et al. Production of cytokines by mouse B-cells: B-lymphomas and normal B-cells produce interleukin-10. Int Immunol 1990; 2: 821-832.

166. Archer CB, Page CP, Morley J, MacDonald DM. Accumulation of inflammatory cells in response to intracutaneous platelet-activating factor (PAF-acether) in man. Br J Dermatol 1985; 112: 285-290.

167. Nagey L, Lee TH, Goetzl EJ, Pickett WC, Kay AB. Complement receptor enhancement and chemotaxis of human neutrophils and eosinophils by leukotrienes and other lipoxygenase products. Clin Exp Immunol 1982; 47: 541-547.

168. Kroegel C, Virchow JC Jr, Luttmann W, Warner JA. Pulmonary immune cells in health and disease. The eosinophil leukocyte. Part I. Eur Respir J 1994; 7: 519-543.

169. Kroegel C, Warner JA, Virchow JC Jr, Matthys H. Pulmonary immune cells in health and disease. The eosinophil leukocyte. Part II. Eur Respir J 1994; 7: 743-760.

170. Wardlaw AJ, Moqbel R, Cromwell O, Kay AB. Plateletactivating factor. A potent chemotactic and chemokinetic factor for human eosinophils. J Clin Invest 1986; 78 : 1701-1706.

171. Juliano RL, Haskill S. Signal transduction from the extracellular matrix. J Cell Biol 1992; 120: 577-585.

172. Hamay MM, Mergenhagen SE, Siraganain RP. Adhesion molecules as regulators of mast cell and basophil function. Immunol Today 1994; 15: 62-66.

173. Sporn SA, Eirman DF, Johnson CE, et al. Monocyte adherence results in selective induction of novel genes sharing homology with mediators of inflammation and tissue repair. J Immunol 1990; 144: 4434-4441.

174. Kornberg L, Earp HS, Turner CE, Prokup C, Juliano RL. Signal transduction by integrins: increased protein phosphorylation caused by clustering of $\beta_{1}$-integrins. Proc Natl Acad Sci USA 1991; 88: 8392-8396.

175. Lipfert L, Haimovitch B, Schaller MD, Cobb BS, Parsons JT, Brugge JS. Integrin-dependent phosphorylation and activation of the protein tyrosine kinase pp125 ${ }^{\mathrm{FAK}}$ in platelets. J Cell Biol 1992; 119: 905-912. 
176. Groux H, Huet S, Valentin HH, Pham D, Bernard A. Suppressor effects and cyclic AMP accumulation by the CD29 of CD4+ lymphocytes. Nature 1989; 339: 152-154.

177. Rybak Me, Renzulli LA. Ligand inhibition of the platelet glycoprotein IIb-IIIa complex function as calcium channel in liposomes. J Biol Chem 1989; 264: 14617 14620.

178. Fujimoto T, Fujimura K, Kuramoto A. Electrophysiological evidence that glycoprotein IIb-IIIa is involved in calcium channel activation on human platelet plasma membranes. J Biol Chem 1991; 266: 16370-16375.

179. Zhang J, Fry MJ, Waterfield MD, et al. Activated phosphoinositide 3-kinase associates with membrane skeleton in thrombin-exposed patients. J Biol Chem 1992; 267: 4686-4692.

180. Jaken S, Leach K, Klauck T. Association of type 3 protein kinase $\mathrm{C}$ with focal contacts in rat embryo fibroblasts. J Cell Biol 1989; 109: 697-704.

181. Lavens SE, Goldring K, Thomas LH, Warner JA. Clustering of $\beta_{1}$-integrins on the surface of human lung mast cells and basophils modifies their response to anti-IgE. J Immunol (Submitted).

182. Casale TB, Wood D, Richerson HB, Zehr B, Zavala D, Hunninghake GW. Direct evidence of a role for mast cells in the pathogenesis of antigen-induced bronchoconstriction. J Clin Invest 1987; 80: 1507-1511.

183. Gomez E, Corrado OJ, Baldwin DL, Swanston AR, Davies RJ. Direct in vivo evidence for mast cell degranulation during allergen-induced reactions in man. $J$ Allergy Clin Immunol 1986; 78: 637-645.

184. Beasley R, Roche WR, Roberts JA, Holgate ST. Cellular events in the bronchi in mild asthma and after bronchial provocation. Am Rev Respir Dis 1989; 139: 806-817.

185. Pesci A, Foresi A, Bertorelli G, Chetta A, Olivieri D. Histochemical characteristics and degranulation of mast cells in epithelial and lamina propria from asthmatics and normal subjects. Am Rev Respir Dis 1993; 147: 684-689.

186. Wenzel SE, Westcott JY, Smith HR, Larson GL. Spectrum of prostanoid release after bronchoalveolar allergen challenge in atopic asthmatics and in control groups. Am Rev Respir Dis 1989; 139: 450-457.

187. Hebda PA, Collins MA, Tharp MD. Mast cell and myofibroblasts in wound healing. Dermatol Clin 1993; 11: 685-696.
188. Jordana M, Befus AD, Newhouse MT, Bienenstock J, Gauldie J. Effect of histamine on proliferation of normal human adult lung fibroblasts. Thorax 1988; 43: 552-558.

189. Crowle PK, Starkey JR. Mast cells and tumour-associated angiogenesis. In: Galli SJ, Austen KF, eds. Mast Cell and Basophil Differentiation and Function in Health and Disease. New York, Raven Press, 1989; pp. 307317.

190. Harveit F. Mast cells and metachromasia in human breast cancer: their occurrence, significance and consequence. A preliminary report. J Pathol 1981; 134: 7-11.

191. Dvorak AM, Galli SJ, Galli AS, Hammond ME, Churchill WH Jr, Dvorak HF. Tumor-basophil interactions in vitro: a scanning and transmission electron microscopic study. J Immunol 1979; 122: 2447-2457.

192. Farram E, Nelson DS. Mouse mast cells as anti-tumour effector cells. Cell Immunol 1980; 55: 294-301.

193. Henderson WR, Chi EY, Jong EC, Klebanoff SJ. Mast cell-mediated tumour cell cytotoxicity. J Exp Med 1981; 153: 520-533.

194. Thornton SC, Mueller SN, Levine EM. Human endothelial cells: use of heparin in cloning and long-term serial cultivation. Science 1983; 222: 623-625.

195. Azizkhan RG, Azizkhan JC, Zetter BR, Folkman J. Mast cell heparin stimulates migration of capillary endothelial cells in vitro. J Exp Med 1980; 152: 931-944.

196. Roche WR. Mast cells and tumours: the specific enhancement of tumour proliferation in vitro. Am J Pathol 1985; 119: 57-64.

197. Vella AT, Hulsebosch MD, Pearce EJ. Schistosoma mansoni eggs induce antigen-responsive CD44-hi Thelper-2 cells and IL-4-secreting CD44-lo cells. Potential for T-helper-2 subset differentiation is evident at the precursor level. J Immunol 1992; 149: 1714-1722.

198. Mahanty S, King CL, Kumaraswami V, et al. IL-4- and IL-5-secreting lymphocyte populations are preferentially stimulated by parasite-derived antigens in human tissue invasive nematode infections. J Immunol 1993; 151: 3704-3711.

199. Gleich GJ, Adolphson CR, Leiferman KM. The biology of the eosinophilic leukocyte. Annu Rev Med 1993; 44: 85-101.

200. Capron A, Dessaint J-P. Immunologic aspects of schistosomiasis. Annu Rev Med 1992; 43: 209-218. 